\title{
SOLID-STATE FERMENTATION MODEL FOR A PACKED-BED BIOREACTOR
}

\author{
C. L. da SILVEIRA ${ }^{1}$, M. A. MAZUTTI ${ }^{1}$ e N. P. G. SALAU ${ }^{1}$ \\ ${ }^{1}$ Universidade Federal de Santa Maria, Departamento de Engenharia Química \\ E-mail para contato: christiansilveira86@gmail.com
}

\begin{abstract}
Simulations can lead to many process advantages, like quality of the product, scaling-up, process control and optimization. However, to turn on the model used in the simulation reliable, it is necessary a good parameter set to fit the experimental data. In this manner, parameter estimation is very important to keep the model adjusted. The main goal of this study is to estimate the parameters of ordinary differential equations set in a solid-state fermentation process model. The process model is composed by a set of seven ordinary differential equations that represents respectively the cells profile, cells physiological state, temperature, substrate consumption and production of ethanol, carbon dioxide and oxygen by the cells metabolism. The model used in this work was statistically validated and the results have shown that it is able to predict the experimental data.
\end{abstract}

\section{INTRODUCTION}

The use of process simulations can lead to advantages, like optimization, process safety, product quality (Zhang et al., 2008), can be economically convenient and facilitate measuring some process variables (Yamada et al., 2005), or even in control developing (Salau et al., 2008). Besides a reliable model, good parameter estimation is required to keep the model adjusted to experimental data, usually through the minimization of an objective function (Schwaab et al., 2008).

In this work is presented a model for a solid-state fermentation (SSF), which is a fermentation process without any free water, i.e. only water that is attached to the substrate cells is available in amount enough to allow microorganisms grow (Pandey, 2003). SSF has lower energy requirements and wastewater production when compared to submerged fermentation, also it can use agroindustrial byproducts as substrate (Mazutti et al., 2010), and has easier products recovery (Rahardjo et al., 2006).

\subsection{Solid-state fermentation modeling}

The model presented in this work is based on the Verhulst Logistic Equation (Verhulst, 1838), on the work of Fanaei and Vaziri (2009) and Silveira et al. (2014). Also, it was included some yield coefficients to predict the substrate consumption, ethanol, $\mathrm{CO}_{2}$ and $\mathrm{O}_{2}$ production. Also, the substrate inhibition hypothesis was used to evaluate the specific growth variable $\mu$, as it can be seen on Equation 1.

$$
\mu=\mu_{\max } S /\left(K_{s}+S+k_{1} S^{2}\right)
$$


Further, the bed density and specific heat algebraic equations (Equations 2-3) were used to support the phenomenological heat transfer equation (Equation 4), which is strongly dependent on the cells growth profile through the metabolic heat term $\left(Y_{Q}\right)$ and based on energy balance.

$$
\begin{aligned}
& \rho_{b}=\varepsilon \rho_{a}+(1-\varepsilon) \rho_{s} \\
& C_{p b}=\left[\varepsilon \rho_{a}\left(C_{p a}+f \lambda\right)+(1-\varepsilon) \rho_{s} C_{p s}\right] / \rho_{b} \\
& \partial T / \partial t=\left[\rho_{s}(1-\varepsilon) Y_{Q}(d X / d t)+\rho_{a} C_{p a} V_{z}(\partial T / \partial z)+\rho_{a} f \lambda V_{z}(\partial T / \partial z)\right] /\left(\rho_{b} C_{p b}\right)
\end{aligned}
$$

The cells growth profile is described by the use of the Verhulst logistic equation with an additional physiological factor state $(\Phi)$. Both equations can be seen on Equation 5 and 6 , respectively.

$$
\begin{aligned}
& d X / d t=\mu \Phi X\left(1-X / X_{m}\right) \\
& d \Phi / d t=\gamma_{s} \Phi\left(1-\Phi^{\alpha}\right)-\gamma_{d} \Phi
\end{aligned}
$$

The coefficients of the physiological state are described by Equations 7 and 8 .

$$
\begin{aligned}
& \gamma_{s}=\gamma_{s 0} \exp \left[-E_{s} /(R(T+273))\right] \\
& \gamma_{d}=\gamma_{d 0} \exp \left[-E_{d} /(R(T+273))\right]
\end{aligned}
$$

The substrate consumption, ethanol, $\mathrm{CO}_{2}$ and $\mathrm{O}_{2}$ production are described by Equation 9 to 12 , respectively.

$$
\begin{aligned}
& d S / d t=Y_{S / X} d X / d t \\
& d P / d t=Y_{P / X} d X / d t \\
& d C O_{2} / d t=Y_{C O 2 / X} d X / d t \\
& d O_{2} / d t=Y_{O 2 / X} d X / d t
\end{aligned}
$$

\subsection{Parameter estimation problem}

The parameters were estimated to fit the model to the experimental data obtained by Mazutti et al. (2010). In section 1.1 the model equations were shown and the parameters chosen to be estimated were: $\mu_{\max }, K_{s}, k_{1}, \mathcal{\varepsilon}, \rho_{s}, C_{p s}, \rho_{a}, \alpha, Y_{S / X}, Y_{P / X}, Y_{C O 2 / X}, Y_{O 2 / X}, Y_{Q}, E_{s}, E_{d}, \gamma_{s 0}$ and $\gamma_{d 0}$. The parameters values, units and descriptions can be found in Table 1.17 parameters were estimated $(\mathrm{NP}=17)$, for 6 experiments $(\mathrm{NE}=6)$ measured at 25 different times $(\mathrm{NY}=25)$. Thus, according to Equation (13), 48 degrees of freedom (DF) were available for the statistical tests.

$$
D F=N E . N Y-N E \cdot N P
$$

The least squares equation was used to the parameter estimation as objective function, cf. Equation 14. 
$\sum F_{\text {obj }}\left(X, T, S, P, C O_{2}, O_{2}\right)=\min \left[f(x), f(T), f(S), f(P), f\left(C O_{2}\right), f\left(O_{2}\right)\right]=\left[\left\|X_{\text {exp }}-X_{\text {mod }}\right\|^{2}, \| T_{\text {exp }}\right.$
$\left.T_{\text {mod }}\left\|^{2},\right\| S_{\text {exp }}-S_{\text {mod }}\left\|^{2},\right\| P_{\text {exp }}-P_{\text {mod }}\left\|^{2},\right\| C O_{2 \text { exp }}-C O_{2 m o d}\left\|^{2},\right\| O_{2 \text { exp }}-O_{2 \text { mod }} \|^{2}\right]$

Where the subscripts exp denotes experimental data and mod denotes modeling data. As smaller the objective function is the better are the parameters estimated for the model, as the residuals will be smaller, i.e. the difference between experimental and simulated data will be more likely.

The software Matlab® function lsqnonlin was used in this work because it solves nonlinear least-squares problems. The chosen algorithm was Levenberg-Marquardt, which consists in an iterative damped least-squares method for minimization of nonlinear functions, it may be subjected to local minimum if a bad initial guess is given (Moré, 1977). Thus, the initial parameter guesses were always updated iteratively until the objective function value stops to change.

\section{MATERIAL AND METHODS}

The experimental data were obtained by Mauztti et al. (2010). The medium of the SFF process was sugarcane bagasse with cane molasses (10 wt \%), corn steep liquor (30 wt $\%)$ and soybean bran $(20 \mathrm{wt} \%)$. The yeast used was Kluyveromyces marxianus NRRL Y-7571. The bioreactor was a cylindrical stainless with air supplier with $95-100 \%$ of water. Inlet and outlet temperatures were monitored by a PT100 (NOVUS, Brazil). The microbial growth was calculated according to the measurements of oxygen uptake rate (Mazutti et al., 2010). Experiments were carried out by 24 hours with data acquisition of all state variables hour by hour. Also, temperature was measured at the bed inlet, $10 \mathrm{~cm}, 20 \mathrm{~cm}$ and $30 \mathrm{~cm}$ from the bed inlet and at the outlet.

The numerical integrator used was the Dormand-Prince pair, based on a Runge-Kutta of $4^{\text {th }}$ and $5^{\text {th }}$ order, which solves non-stiff differential equations (Dormand and Prince, 1980). The computer used for the procedures has an Intel ${ }^{\circledR}$ Core $^{\mathrm{TM}} \mathrm{i} 7-3770$ with $3.40 \mathrm{GHz}$ processor and 12 Gb of RAM memory and it is running with the Windows 764 bits Operating System.

\section{RESULTS AND DISCUSSION}

As referred in item 1.2, Table 1 presents the estimated parameters obtained after several estimations with initial parameters guesses corrected after each estimation until the residuals become unalterable. The means and confidence intervals of the estimated parameters for each experiment dataset were computed according to Draper and Smith (1998) and Schwaab and Pinto (2007) works.

Table 1 - Estimated parameters (95\% of confidence)

\begin{tabular}{|c|c|c|c|}
\hline Parameter & Substrate Inhibition & Units & Definitions \\
\hline$\mu_{\max }$ & $0.8243 \pm 0.0438$ & $\mathrm{~h}^{-1}$ & Maximum growth rate \\
\hline $\mathrm{K}_{\mathrm{s}}$ & $0.00024 \pm 0.0149$ & $\mathrm{~g} / \mathrm{L}$ & Half-velocity constant \\
\hline $\mathrm{k}_{1}$ & $-0.3109 \pm 0.0787$ & $\mathrm{~L} / \mathrm{g}$ & Dissociation constant \\
\hline$\varepsilon$ & $0.9991^{*}$ & {$[-]$} & Void fraction \\
\hline$\rho_{\mathrm{s}}$ & $269.9952^{*}$ & $\mathrm{~kg} \cdot \mathrm{m}^{-3}$ & Substrate density \\
\hline $\mathrm{C}_{\mathrm{ps}}$ & $2499.9575^{*}$ & $\mathrm{~J} . \mathrm{kg}^{-1} \cdot{ }^{\circ} \mathrm{C}^{-1}$ & Heat capacity of substrate \\
\hline
\end{tabular}




\begin{tabular}{|c|c|c|c|}
\hline$\rho_{\mathrm{a}}$ & $0.9000^{*}$ & $\mathrm{Kg} \cdot \mathrm{m}^{-3}$ & Moist air density \\
\hline$\alpha$ & $11.0000^{*}$ & {$[-]$} & Physiological exponent \\
\hline $\mathrm{Y}_{\mathrm{x} / \mathrm{s}}$ & $1.0241 \pm 0.0329$ & $\mathrm{~g} / \mathrm{g}$ & Substrate to cells yield coefficient \\
\hline $\mathrm{Y}_{\mathrm{P} / \mathrm{x}}$ & $1.0160 \pm 0.0097$ & $\mathrm{~g} / \mathrm{g}$ & Cells to product yield coefficient \\
\hline $\mathrm{Y}_{\mathrm{x} / \mathrm{O} 2}$ & $0.9835 \pm 0.0091$ & $\mathrm{~g} / \mathrm{g}$ & Cells to $\left[\mathrm{O}_{2}\right]$ yield coefficient \\
\hline $\mathrm{Y}_{\mathrm{x} / \mathrm{CO} 2}$ & $0.9392 \pm 0.0140$ & $\mathrm{~g} / \mathrm{g}$ & Cells to [CO $\mathrm{CO}_{2}$ yield coefficient \\
\hline $\mathrm{Y}_{\mathrm{q}}$ & $8.3660 \mathrm{E}+06^{*}$ & $\mathrm{~J} . \mathrm{kg}_{\mathrm{cells}}{ }^{-1}$ & Metabolic heat coefficient \\
\hline $\mathrm{E}_{\mathrm{s}}$ & $6.8137 \mathrm{E}+04^{*}$ & $\mathrm{~J} \cdot \mathrm{mol}^{-1}$ & Activation energy for the physiological factor \\
\hline $\mathrm{E}_{\mathrm{d}}$ & $2.9451 \mathrm{E}+05^{*}$ & $\mathrm{~J} \cdot \mathrm{mol}^{-1}$ & Activation energy for the physiological factor \\
\hline$\gamma_{\mathrm{s} 0}$ & $9.7603 \mathrm{E}+08^{*}$ & $\mathrm{~h}^{-1}$ & Frequency factor for the physiological \\
\hline$\gamma_{\mathrm{d} 0}$ & $8.7400 \mathrm{E}+45^{*}$ & $\mathrm{~h}^{-1}$ & Frequency factor for the physiological \\
\hline
\end{tabular}

* Confidence interval too narrow $(<\mathrm{E}-05)$.

For these parameters, the objective function value, cf. Equation 14, was found to be 11.2542. Also, Student's t-test and the Fisher's exact test were performed to verify if the means and the variances of the models correspond to the experimental data. The test results of the Student's ttest, as they can be seen in Table 2, have shown that the means for the model are correspondent to the experimental data, because their confidence intervals intercept each other.

Table 2 - Student's t-test for all state variables

\begin{tabular}{|c|c|c|c|}
\hline & Cells & Temperature & Total Reduced Sugar \\
\hline Experimental & $0.6237<\mu<0.7560$ & $0.4702<\mu<0.5399$ & $0.1932<\mu<0.2943$ \\
\hline Model & $0.5904<\mu<0.7121$ & $0.4346<\mu<0.4991$ & $0.2198<\mu<0.3386$ \\
\hline & Ethanol & $\mathrm{O}_{2}$ & $\mathrm{CO}_{2}$ \\
\hline Experimental & $0.6237<\mu<0.7560$ & $0.6237<\mu<0.7560$ & $0.6237<\mu<0.7560$ \\
\hline Model & $0.5996<\mu<0.7232$ & $0.6000<\mu<0.7237$ & $0.6283<\mu<0.7579$ \\
\hline
\end{tabular}

Fisher's exact test results, cf. Table 3, have shown that the limits corresponds to the variances ratio, denoting that, equally, they cannot be distinguished from the experimental variances.

Table 3 - Fisher's exact test for all state variables (lower limit $<\left(S_{\text {exp }}{ }^{2}\right) /\left(S_{\text {mod }^{2}}\right)<$ upper limit)

\begin{tabular}{|c|c|c|}
\hline Cells & Temperature & Total Reduced Sugar \\
\hline $0.6669<1.2184<1.5728$ & $0.6669<0.7223<1.5728$ & $0.6669<0.7464<1.5728$ \\
\hline Ethanol & $\mathrm{O}_{2}$ & $\mathrm{CO}_{2}$ \\
\hline $0.6669<1.1803<1.5728$ & $0.6669<1.1787<1.5728$ & $0.6669<1.0748<1.5728$ \\
\hline
\end{tabular}




\subsection{Model simulations}

Model simulations were performed with the estimated parameters in order to visually compare the simulated data to the experimental data. Figures 1-2 show the experimental data versus the model only for cells growth and temperature profiles for three experiments. These figures show how close the model is from the process, confirming what was seen in Tables 2 and 3.
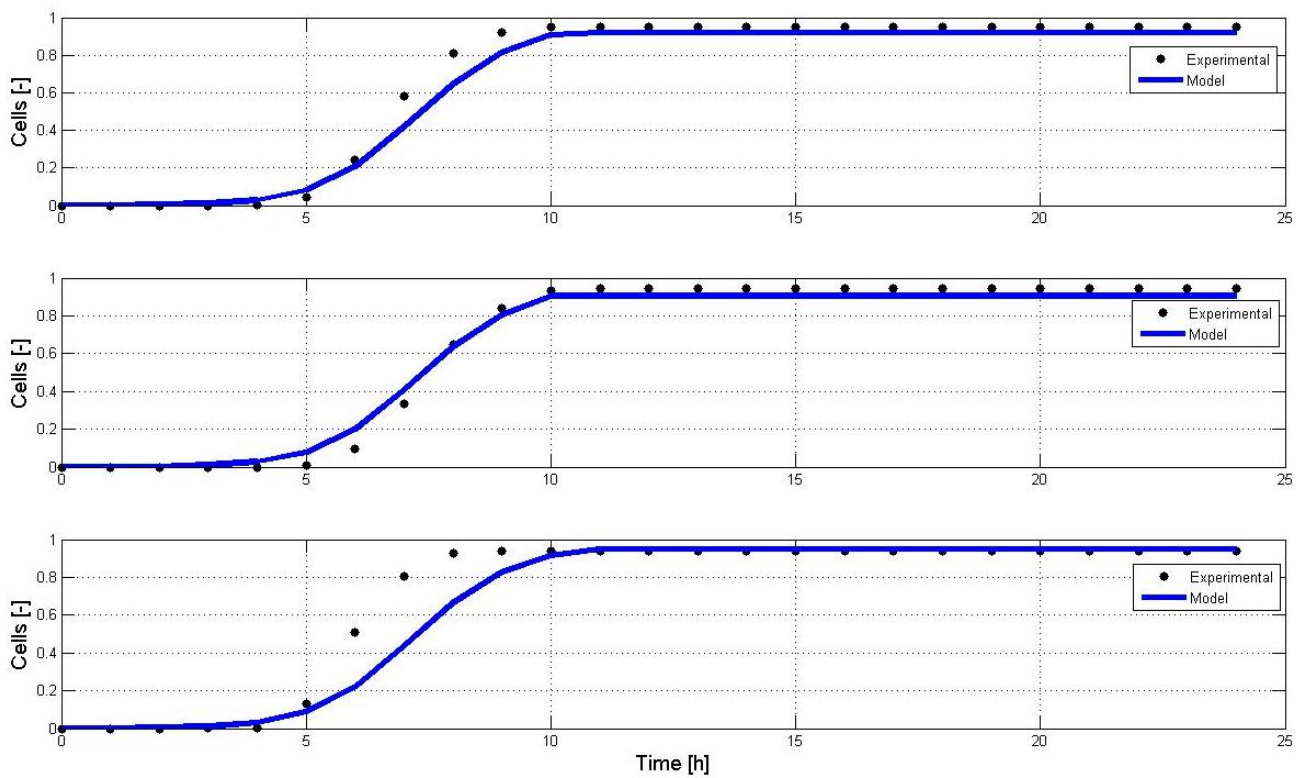

Figure 1 - Cells growth profile versus time for experimental and model data.
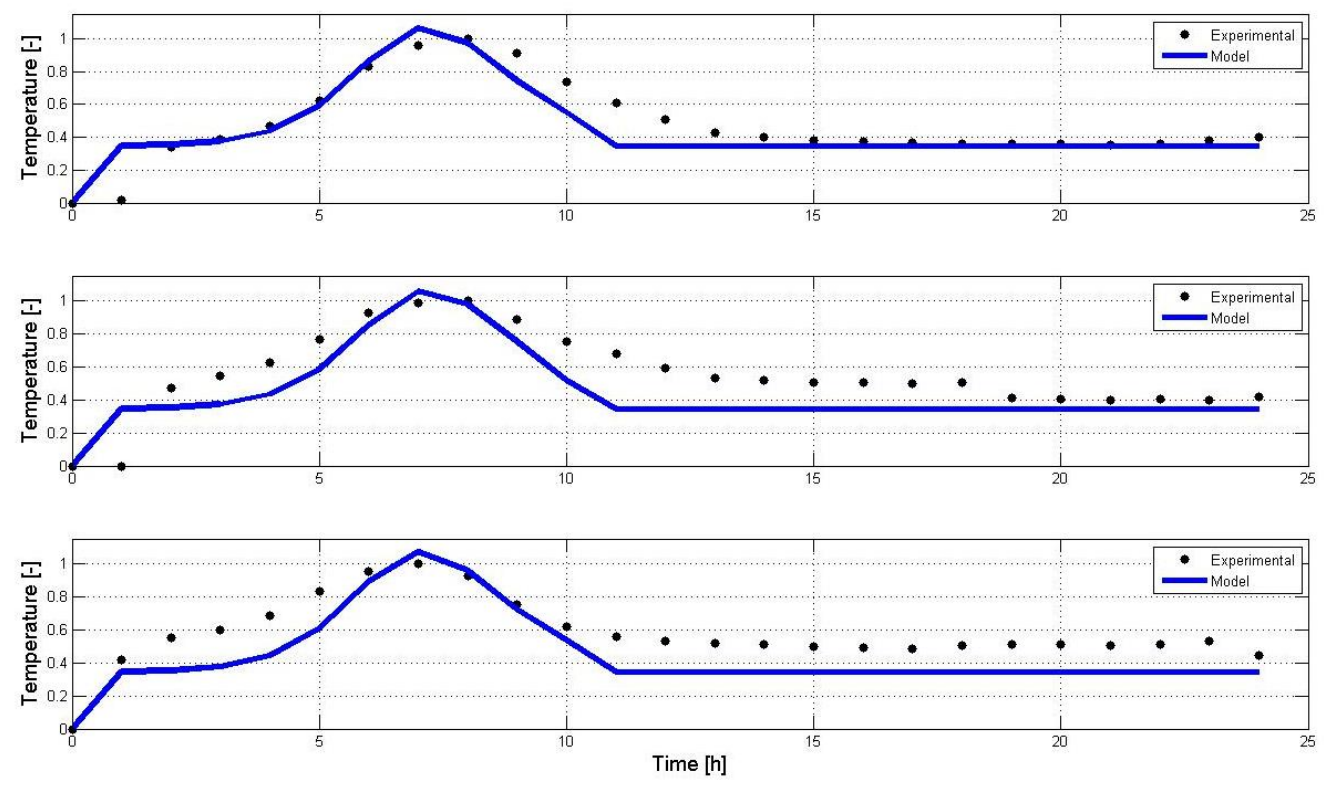

Figure 2 - Temperature profile versus time for experimental and model data. 


\section{CONCLUSIONS}

According to Table 2, the state variables means cannot be distinguished between experimental and model data. It can be also seen on Table 3 that the variances of the model and the experiments are equivalent. Thus, the model with the parameters that were estimated, cf. Table 1, cannot be distinguished from the experimental data. In other words, the whole model is able to describe a solid-state fermentation using the Kluyveromyces marxianus NRRL Y-7571.

Moreover, the objective function is low, considering the amount of data analyzed. According to the results the model has presented a good agreement with the experimental data. The temperature profile seems to have a minor delay, however the behavior is much like the experimental data.

\section{REFERENCES}

DORMAND, J. R.; PRINCE, P. J. A family of embedded Runge-Kutta formulae. Journal of Computational and Applied Mathematics, v. 6(1), p. 19-26, 1980.

FANAEI, M. A.; VAZIRI, B. M. Modeling of temperature gradients in packed-bed solid-state bioreactors. Chem. Engineering and Processing: Process Intensification, v. 48(1), p. 446-451, 2009.

MAZUTTI, M. A.; ZABOT, G.; BONI, G.; SKOVRONSKI, A.; OLIVEIRA, D. de; LUCCIO, M. Di; RODRIGUES, M. I.; TREICHEL, H.; MAUGERI, F. Kinetics of inulinase production by solid-state fermentation in a packed-bed bioreactor. Food Chemistry, v. 120, p. 163-173, 2010.

MORÉ, J. J. The Levenberg-Marquardt Algorithm: implementation and theory. Numerical Analysis, Ed. G. A. Watson, Lectures Notes in Mathematics 630, Springer Verlag, p. 105-116, 1977.

PANDEY, A. Solid-state fermentation. Biochemical Engineering journal, v. 13, p. 81-84, 2003.

RAHARDJO, Y. S. P.; TRAMPER, J.; RINZEMA, A. Modeling conversion and transport phenomena in solid-state fermentation: a review and perspectives. Biotechnology Advances, v. 24, p. 161-179, 2006.

SALAU, N. P. G.; NEUMANN, G. A.; TRIERWEILER, J. O.; SECCHI, A. R. Dynamic behavior and control in an industrial fluidized-bed polymerization reactor. Industrial \& Engineering Chemistry Research, v. 47 (16), p. 6058-6069, 2008.

SCHWAAB, M.; BISCAIA, E. C.; MONTEIRO, J. L. Jr.; PINTO, J. C. Nonlinear parameter estimation through particle swarm optimization. Chem. Eng. Science, v. 63, p. 1542-1552, 2008.

SILVEIRA, C. L. da; MAZUTTI, M. A.; SALAU, N. P. G. Modeling the microbial growth and temperature profile in a fixed-bed bioreactor. Bioprocess and Biosys. Eng., Published online (2014).

VERHULST, P. F. Notice sur la loi que la population poursuit dans son accroissement. 
Correspondance mathématique et physique, v. 10, p. 113-121, 1838.

YAMADA, H.; CHAYAHARA, A.; MOKUNO, Y.; SODA, Y.; HORINO, Y.; FUJIMORO, N. Modeling and numerical analyses of microwave plasmas for optimizations of a reactor design and its operating conditions. Diamond \& related material, v. 14, p. 1776-1779, 2005.

ZHANG, Y.; LI, C.; HE, X.; CHEN, B. Simulation and optimization of toluene liquid-phase catalytic oxidation. Chinese Journal of Chemical Engineering, v. 16(1), p. 36-38, 2008. 